\title{
Preemption of Local Governmental Ordinances Regulating Concentrated Animal Feeding Operations in the United States
}

\author{
Terence J. Centner ${ }^{1}$ \& Jessica E. Alcorn ${ }^{2}$ \\ ${ }^{1}$ Department of Agricultural and Applied Economics, The University of Georgia, Athens, USA \\ ${ }^{2}$ School of Public and Environmental Affairs, Indiana University, Bloomington, USA \\ Correspondence: Terence J. Centner, Department of Agricultural and Applied Economics, 313 Conner Hall, The \\ University of Georgia, Athens, GA 30602, USA. Tel: 706-542-0756. E-mail: Tcentner@uga.edu
}

\author{
Received: January 16, 2015 Accepted: February 5, 2015 Online Published: March 30, 2015 \\ doi:10.5539/ep.v4n2p66 URL: http://dx.doi.org/10.5539/ep.v4n2p66
}

Funding: This work was supported by the Cooperative State Research Education and Extension Service, US Department of Agriculture, grant GEO00684.

\begin{abstract}
Public discontent with practices accompanying the production of food animals has led to requests to increase governmental oversight of pollutants. In the United States, special attention has focused on animal waste disposal practices at concentrated animal feeding operations. Communities concerned with environmental quality want to enact local ordinances to regulate objectionable activities. Simultaneously, state legislatures also regulate these activities, and a state comprehensive regulatory system may preempt ordinances of local governments. An investigation of issues posed by livestock facilities shows that local governments should retain authority to enact local ordinances addressing negative externalities from livestock operations.
\end{abstract}

Keywords: animal waste, CAFOs, local government, preemption, water pollution, odors

\section{Introduction}

The United States Government Accountability Office (2008) reports that nearly one-half of the animals raised for food in the United States are produced at large concentrated animal feeding operations (CAFOs). The concentration of animals allows for efficient production of meat, dairy, and poultry products that contribute to low food prices. Yet this method of production is accompanied by problems created by large quantities of animal waste. Surface and groundwater pollution may occur, and odors and health risks can adversely affect neighbors. The negative externalities accompanying the production of animals at CAFOs have led legislative bodies at the federal, state, and local levels to adopt regulatory controls.

CAFOs were prominent in public debate at the national level during the 1990s and 2000s due to litigation by environmental groups against the US Environmental Protection Agency (EPA) concerning federal water pollution permitting requirements. However, objectionable odors associated with animal production facilities have also led citizens to petition US state and local governments for additional controls. Some state legislatures responded with livestock facility siting laws, which may cover more facilities than just CAFOs. Yet these efforts did not quiet demands for additional proscriptions. Citizens continued their quest by petitioning local governments to regulate pollution and odors by limiting the locations and activities of livestock facilities. Depending upon the individual US state, local governments include counties, townships, towns, villages, and cities.

Business interests and agricultural groups have opposed additional regulations due to the costs associated with each new control (Collins, 2012; US Department of Agriculture, 2003). With respect to water pollution, the groups espoused exceptions from water permitting provisions and sought to keep nutrient management plans confidential. For nuisances, agricultural groups convinced every state legislature to enact an anti-nuisance law. Another approach taken by some groups has been to advance state regulations that preempt more specific local requirements. This often involves moderate controls under state law that preclude stricter local controls enabling livestock producers to avoid costs associated with local regulations. 
The issue of whether a state law governing livestock preempted local controls was considered in Adams v. Wisconsin Livestock Facilities Siting Review Board (2012). A livestock producer had applied for a permit under a town ordinance for a facility to house additional numbers of animals. The town granted the permit but imposed several conditions it felt necessary to protect surface waters. The applicant challenged five of the conditions in a lawsuit claiming the state livestock facility siting law preempted the additional conditions imposed by the town. The court found that the town could not proceed beyond the state's law to impose further conditions including more stringent nutrient management plans and reporting requirements. Because the state legislature had expressly withdrawn the power of the town to impose additional requirements in livestock facility siting permits, the challenged conditions were invalid.

This case highlights the significance of preemption. Because state legislatures are the source of local governmental powers, they are able to add or subtract from these powers, including the enactment of a comprehensive regulatory system that precludes local regulation. If state regulations cover issues of statewide concern and are intended to occupy the entire field, local governments cannot enact ordinances or local laws (collectively called "ordinances") prescribing additional requirements on the subject. Citizens may be precluded from addressing local issues such as the number of animals at a farm or water pollution. State preemption of local ordinances dealing with agricultural and land uses has precluded local governments from regulating numerous agricultural and land use topics (see Table 1). These examples show that interest groups have curtailed multiple sets of regulations by state and local governments.

Table 1. Agricultural and land use topics for state preemption of local laws

\begin{tabular}{|c|c|c|}
\hline Topic & Example: Citation by statute or judicial decision & $\begin{array}{l}\text { Further } \\
\text { explanation }\end{array}$ \\
\hline Agricultural nuisances & Township of Franklin v. den Hollander, 2002 & Centner, 2006 \\
\hline Farm structures & Commonwealth v. Richmond Township, 2010 & Carter, 2007 \\
\hline Forestry practices & Oregon Revised Statutes $§ 527.722,2014$ & $\begin{array}{l}\text { Sullivan \& } \\
\text { Solomou, } 2011\end{array}$ \\
\hline $\begin{array}{l}\text { Genetically engineered } \\
\text { seed and seed use }\end{array}$ & $\begin{array}{l}\text { Kansas Annotated Statutes } \S 2-1450,2013 \text {; Oklahoma } \\
\text { Statutes tit. } 2, \S 8-26.1,2014\end{array}$ & Endres, 2006 \\
\hline Hog farm laws & Craig v. County of Chatham, 2002 & Noel, 2002 \\
\hline $\begin{array}{l}\text { Land application of } \\
\text { sludge }\end{array}$ & $\begin{array}{l}\text { Official Code of Georgia } \S 12-5-30.3,2013 \text {; Franklin County } \\
\text { v. Fieldale Farms Corp., } 1998\end{array}$ & Griffith, 2004 \\
\hline $\begin{array}{l}\text { Livestock care and } \\
\text { handling }\end{array}$ & $\begin{array}{l}\text { Iowa Code } \S 331.304 \mathrm{~A}, 2013 \text {; South Carolina Code } \\
\text { Annotated } \S 47-4-160,2013\end{array}$ & Springsteen, 2009 \\
\hline Livestock production & $\begin{array}{l}\text { Iowa Code } \S 331.304 \mathrm{~A}, 2013 \text {; Worth County Friends of } \\
\text { Agriculture v. Worth County, } 2004\end{array}$ & Novak, 2000 \\
\hline $\begin{array}{l}\text { Nutrient management for } \\
\text { animal waste }\end{array}$ & $\begin{array}{l}\text { Pennsylvania Consolidated Statutes, tit. 3, § 519, 2013; } \\
\text { Burkholder v. Zoning Hearing Board of Richmond Township, } \\
2006\end{array}$ & $\begin{array}{l}\text { Simpson et al., } \\
2008\end{array}$ \\
\hline $\begin{array}{l}\text { Production of farm } \\
\text { products }\end{array}$ & Official Code of Georgia $\S 2-1-6,2013$ & Springsteen, 2009 \\
\hline Water contamination & $\begin{array}{l}\text { Wisconsin Statutes ch. 93.90, 2012; Adams v. Wisconsin } \\
\text { Livestock Facilities Siting Review Board, } 2012\end{array}$ & Hansen, 1999 \\
\hline
\end{tabular}

CAFOs present states and communities with challenges due to concentrations of animal wastes that may adversely affect local water supplies and foul the air. Can state legislatures adequately deal with these issues or should local communities be able to enact additional controls needed to protect the health and well-being of their citizens? This paper explores the regulation of livestock facilities, discusses rationales for preemption, and identifies arguments for local ordinances to regulate pollutant discharges and negative features related to livestock production. The analysis recommends limiting preemption to comprehensive regulatory systems addressing a subject for which the state has demonstrated complete oversight. 


\section{Regulatory Provisions Governing CAFO Water Pollution}

With the adoption of the Clean Water Act (CWA) in 1972, the United States Congress set ambitious goals to clean up rivers, lakes, and other bodies of water by making discharges of pollutants from identifiable sources illegal, unless authorized by a permit. The CWA prohibits the discharge of pollutants into waters of the United States from point sources except as authorized under the National Pollutant Discharge Elimination System (NPDES) program (US Code, 2012). A "point source" of pollution means a discernible and discrete conveyance from which pollutants are discharged and includes CAFOs (US Code, 2012). The EPA is in charge of developing federal regulations that implement the CWA's NPDES permitting requirements and developed a CAFO rule (US Code of Federal Regulations, 2014). Permittees adopt technologies that enable them to meet the effluent limitations set forth in their permits.

The CAFO rule prescribes regulatory provisions for CAFOs' physical areas of production as well as land application areas that have discharges (Centner \& Newton, 2008; US Code of Federal Regulations, 2014). Although land application performed correctly involves the use of a sustainable agronomic practice, land application of manure may result in overapplication due to lack of enough land (Paudel \& McIntosh, 2005) or due to the expense of hauling manure (Paudel et al., 2009). The overapplication of manure is not permitted under the CAFO regulations because it may result in excessive amounts of nutrients accumulating in soils that are carried into waterbodies. For the land application of manure by Large CAFOs, a nutrient management plan that minimizes nutrient movement to surface waters is required (US Code of Federal Regulations, 2014).

The EPA has delegated authority to issue NPDES permits to 45 states so different state regulations govern the issuance of permits to nearly all of the country's CAFOs. State regulatory programs illustrate different approaches for siting requirements, waste application limitations, monitoring, reporting obligations, and educational requirements to protect environmental quality. Some states require permitting for smaller livestock operations or have nutrient management plans with more detailed best management practices (Centner, 2012). Other states outline minimum buffer distances between areas containing wastes and water conduits, property lines, residences, or other buildings to prevent surface water impairment (Missouri Code of State Regulations, 2013).

Enforcement of the NPDES permitting process also varies since it is dependent upon the willingness of the regulatory agency to enforce pollution controls and the resources the state allocates for enforcement personnel and oversight. States placing a greater emphasis on economic benefits related to attracting business activities may not be as concerned about enforcing their NPDES permitting programs. Disparities among states are not surprising because each state is responding to a different set of factors, including citizen ideology, share of gross state product from agriculture, and representation of politicians on legislative committees related to business and environmental issues (Helland, 1998).

Animal operations that are not regulated by the CAFO rule are subject to state nonpoint pollution regulations that incorporate best management practices to reduce pollutant discharges (Burt et al., 2013). Each state identifies best management practices that can be used to control nonpoint sources of pollution and encourages their adoption. However, it is too cumbersome for states to monitor the use of best management practices in controlling nonpoint-source pollution. In general, there is no state or federal oversight over water pollutants coming from non-CAFOs (Dowd et al., 2008).

\subsection{State Laws and Local Ordinances}

Federal and state provisions addressing water pollution from livestock facilities only address the impairment of surface waters. Due to other negative externalities, state and local governments have adopted regulations to regulate odors, health issues, and nuisances. One group of provisions is local siting ordinances to limit locations of future livestock facilities (Adams v. Wisconsin Livestock Facilities Siting Review Board, 2012; Cronauer, 2011). State livestock siting laws are intended to ameliorate issues between CAFOs and neighbors (Illinois Compiled Statutes Annotated, 2013). They prescribe setback requirements and preclude new and expanded CAFOs from being located too close to existing residences or other incompatible land uses. However, they decline to regulate all livestock facilities. For example, the Illinois legislation only applies to operations with lagoons or more than 1,000 animal units (Illinois Compiled Statutes Annotated, 2013).

The major reason for siting provisions is the denigration of air quality. Large quantities of animal manure can lead to overwhelming odors that preclude neighbors from engaging in normal day to day activities (Murphy, 2008). Odors may also lead to health problems (Dalton et al., 2011). Odors from livestock facilities are so significant that they negatively affect home values (Palmquist et al., 1997; Isakson \& Ecker, 2008). A study from Iowa found that there may be a $9 \%$ drop in property value if a moderately-sized livestock operation is located 
upwind and near a residence (Herriges et al., 2005).

Livestock facility siting laws may also address other issues. Some siting laws have provisions on water contamination (Illinois Compiled Statutes Annotated, 2013). Others limit the location of livestock facilities to reduce the risks of health problems (Wisconsin Statutes, 2012) and to safeguard recreational opportunities (Illinois Compiled Statutes Annotated, 2013).

Every state legislature has also addressed the conflicts arising from agricultural nuisances by adopting an anti-nuisance law, also called a right-to-farm law (Centner, 2006). Anti-nuisance laws embody a policy decision to support business activities by reducing situations under which nuisance law can be used to end an activity. Under an anti-nuisance law, the balance of competing property rights is changed so objectionable activities are condoned in qualifying situations. The laws embrace the concept that persons moving next to smelly or offensive agricultural operations accept the annoying activities as part of their choice to live in the country.

State anti-nuisance laws were written to preempt local nuisance legislation (Township of Franklin $v$. den Hollander, 2002). A local government cannot enact an ordinance making an activity a nuisance if the activity qualifies under the exception set forth by the state anti-nuisance law. Although nuisance is a local issue, legislatures decided the economic detriment to agricultural producers was significant enough to merit overruling nuisance law in qualifying situations.

\subsection{Preemption of Local Ordinances}

The identification of state laws and local ordinances regulating livestock production show multiple options for responding to public concerns about CAFOs. Yet as demonstrated by state anti-nuisance legislation, the ability of local governments to act may be limited. States determine what powers they grant to local governments as well as limitations on local governments. States are able to enact laws that preclude local regulations, including local ordinances. Whenever a state preempts local governmental action, it affects businesses and citizens.

State preemption of local regulation may occur due to express preemption, a conflict with state law, or implied field preemption (Rosenbloom, 2012). Express preemption means that the legislature has enunciated that its law precludes actions by local governments. If an ordinance is found to conflict with a state law, it is implied that the provision or ordinance is preempted. In other cases, a court may find that the state intended to occupy the entire field of regulation for a particular subject so that implied field preemption precludes local controls (Perkins, 2009). For implied preemption questions, the analysis includes an examination of the local powers granted by the state and whether a subsequent state law takes away the earlier-granted powers for a subject (Perkins, 2009).

With the continual adoption of new state laws, it is not always clear whether a law intends to preempt local regulation. Some state legislative provisions contemplate concurrent activities at the state and local levels that may create confusion on what local governments can do. Additional confusion may exist when a state legislature adopts a law that prohibits local governments from adopting "unauthorized local ordinances" (Pennsylvania Consolidated Statutes, 2013). Implied preemption normally requires a reasonable inference that the legislature left no room for local regulation or a state's comprehensive regulatory system is so dominant that it precludes a local ordinance on the same subject.

Determining whether implied preemption invalidates a local ordinance is more difficult. In some cases, a court may conclude that the state's provisions occupied the field sufficiently to demonstrate a legislative intent to preempt local ordinances dealing with water quality. However, if the state's regulations recognize a role of local governments in adding ordinance provisions on unique local conditions, the state's law would not preempt additional county regulations approved by the state agency (Canadian Connection v. New Prairie Township, 1998). Controversies about the meaning of legislative grants will lead to lawsuits in which courts will determine whether a state law preempts local ordinances on the same subject (Ramsey County Farm Bureau v. Ramsey County, 2008).

\section{Discussion}

The concerns that accompany the production of food animals at CAFOs raise questions of whether a state's legislature should preempt local regulations. To address state preemption, the major categories of negative externalities are distinguished. The identification of separate problems discloses that states are not in a superior position to regulate localized externalities. Next, what are the advantages and disadvantages that accompany preemption of local regulations? Separate rationales for state preemption and arguments supporting local regulation are evaluated. By analyzing the factors required to establish implied preemption, local governments might discern ways to structure ordinances regulating negative externalities accompanying the production of livestock so they do not address the subject matter of a state law. 


\subsection{Externalities from Livestock Facilities}

The description of state laws and ordinances that have been enacted to address externalities from livestock production identified four issues: surface water quality, groundwater contamination, odors, and health risks. Each of these issues may be analyzed separately to determine whether a state or local government is in the best position to effectively ameliorate the negative effects of livestock production practices (Table 2).

For surface water quality, the state has a keen interest in protecting downstream water users. However, local governments may observe localized pollution risks and desire to add to the regulatory protections that the state has implemented to preclude contamination. Thus, it may be desirable to have both state and local governments involved in overseeing surface water quality. A similar situation exists for groundwater contamination. Both state and local governments have strong interests in precluding contamination.

Table 2. Analyzing a comprehensive regulatory system to defeat implied field preemption

\begin{tabular}{ll}
\hline Factor & Circumstances showing no implied field preemption \\
\hline No significant policy justification & $\begin{array}{l}\text { Establish that there is no need for uniform regulations or that } \\
\text { livestock is not important to the economy of the state }\end{array}$ \\
Allows local action & $\begin{array}{l}\text { By allowing local regulations, a state law fails to demonstrate } \\
\text { exclusivity of state concern }\end{array}$ \\
Bnregulated facilities and pollutants & $\begin{array}{l}\text { By not regulating small livestock facilities and non-point-source } \\
\text { pollutants, the state does not have a comprehensive regulatory } \\
\text { system }\end{array}$ \\
Unacceptable local pollution & $\begin{array}{l}\text { There is no regulation of these pollutants by the state so } \\
\text { ordinances are not preempted }\end{array}$ \\
\hline
\end{tabular}

Turning to odors and health risks, the persons most affected are those in the immediate vicinity of a livestock facility. Odors and health risk externalities tend to be localized (Rumsey \& Aneja, 2014). This means that state governments cannot effectively deal with them, and local governments have the greatest interest in reducing unreasonable activities that adversely affect neighbors. Moreover, state legislatures have generally deferred to local governments on these issues, including the delegation of health issues to local public health departments (Gostin, 2008). Local citizens deserve an opportunity to express themselves through the adoption of ordinances that enhance the quality of their communities.

\subsection{Rationales for State Preemption}

Proponents of preemption offer several significant reasons to support the adoption of state legislation that precludes ordinances on the same subject by local governments: uniform regulations, greater expertise, economic importance, and fewer regulatory costs.

The justification most often cited by proponents of preemption is the desire for consistent regulations in all areas of the state (Perkins, 2009). By precluding additional local ordinances on a subject, preemption by a state establishes uniform regulations offering greater certainty for businesses and regulators. Firms doing business in more than one municipality will not have to be knowledgeable of different requirements. Uniformity reduces inequities between and within communities and helps reduce controversies and costly legal challenges. Regulation at the state level may also reduce arbitrary and capricious decisions related to political friendships or personal connections.

Due to resources available to a state agency, its staff is able to develop greater expertise in dealing with regulated concerns (Town of Pelham v. Browning Ferris Industries of New Hampshire, Inc., 1996). For some CAFO issues, states may already have staff overseeing related aspects of environmental quality. Given the enhanced expertise of state staff, adopted regulations should pose fewer issues and problems for regulated facilities.

State preemption of local ordinances fosters a favorable business climate that may be important for maintaining and attracting business firms. A state may decide that preemption is needed because local governments are too focused on the well-being of their residents and do not always consider state and regional interests when they enact local ordinances (Ostrow, 2011). Over the past several decades, the amount of land and number of jobs dedicated to agriculture has markedly declined. As a result, state legislators may consider the economic viability of CAFOs as part of its desire to encourage the production of animal products. A single process for securing 
permission means livestock producers will have fewer costs.

Preemption involving a single set of state regulations allows regulatory agencies to garner economies of scale and centralized control. The absence of duplicative staff at the local level presages fewer governmental regulators to oversee the regulated activity.

\subsection{Arguments Supporting Local Ordinances}

Local governments adopt ordinances for multiple reasons. The negative externalities associated with CAFOs and other circumstances support the enactment of local ordinances to enhance the welfare of people living nearby.

Local governments may decide that they need to protect the public health of their citizens from groundwater contamination. If groundwater becomes contaminated, those who live in the area are the most affected (Spence, 2013). This suggests that the government closest to those affected would have a superior ability to address localized risks of groundwater contamination.

State CAFO and livestock facility siting regulations decline to regulate all producers. The EPA estimates that less than ten percent of confined animal feeding operations are CAFOs (US EPA, 2011). This suggests that copious amounts of animal waste are not regulated through the NPDES permitting program. Moreover, large CAFOs may not be the worst polluters. A study of large swine operations discerned that they were more progressive in their nutrient management practices as compared to small operations (Hassinger et al., 2000). Animal numbers at a single operation may form a starting point for regulatory controls, but by itself may not be an accurate predictor of environmental degradation.

Furthermore, agricultural nonpoint source pollution from animals is not effectively regulated by states (Dowd et al., 2008). A report by the EPA in 2013 shows some states with low percentages of CAFOs with NPDES permits (US EPA, 2013). Various reasons may exist for the paucity of enforcement, including a state's interest in the "race to the bottom" in which the state chooses to offer a more favorable regulatory climate for animal agriculture (Groves, 2012). Due to the absence of state controls over all surface water pollutants from many livestock facilities, local governments may decide that localized water pollution needs to be addressed in an ordinance.

CAFO regulations depend on self-reporting by CAFO owners and operators (Groves, 2012; Jerger, 2004), and are not always enforced by state agencies due to the lack of sufficient personnel (Copeland, 2010). Agricultural pollution impairs more miles of streams than any other source (US EPA, 2009, p. 16). High nutrient levels of nitrogen and phosphorous can negatively impact local communities when eutrophication denigrates local water resources (Mallin \& Cahoon, 2003). These circumstances suggest that additional local controls for water pollution from livestock facilities may be needed.

One of the main objectives of local siting ordinances is to control odors that are offensive to nearby residents (Endres \& Grossman, 2004). The objectionableness of odors is dependent on source odor emission rates, topography, weather conditions, wind speed and direction, solar radiation, relative humidity, and air mixing height (Pan et al., 2007). State siting regulations exempt too many facilities and state governments are unable to employ sufficient technology for devising regulations that can meaningfully address odors in local communities.

Because livestock production may be accompanied by flies and air pollutants that create risks of negative respiratory and neurobehavioral effects on humans (Dalton et al., 2011), a local government may decide that an ordinance is required to protect neighbors. Local governments may be able to address health issues more effectively than a state government (Hackney, 2010). They have a greater incentive to protect their citizens and some health threats are inherently local in nature.

States with large populations, sparsely populated areas, varied geographies, and other differences may not enact laws and regulations that work well for all areas of the state. Local governments are intended to facilitate different regulatory controls in dissimilar areas. For issues concerning livestock production, a state legislature controlled by representatives from urbanized districts may fail to recognize the needs of rural areas. For these issues, allowing local governments to control externalities from livestock production is appropriate.

Local governments are especially valuable for serving as laboratories of experimentation in achieving environmental goals. This experimentation has become important in restricting harm to human health and the environment (Glicksman, 2006), the very objectives cited for responding to externalities from CAFOs. Depending on the situation, devolving policy making to local governments allows regulatory experimentation that draws upon local expertise and the experiences of persons affected by a problem. While local innovation will not always lead to desirable results, those regulations that are successful can be transferred to other local and state governments (Parlow, 2008). 


\subsection{Preemption by a Comprehensive Regulatory System}

Although state legislatures have the ability to preempt local issues, authorization given to local governments confirms that states feel local governments are important for overseeing matters of local concern. Implied field preemption is reserved for issues where the regulatory structure consists of a comprehensive regulatory system that expresses a strong state presence to regulate an issue. In these situations, it may be said that the state has "captured" the issue so it is appropriate not to allow further regulation at the local level.

For the separate issues related to the regulation of livestock production noted in Table 2, two have been somewhat captured by most state governments: regulation of surface water quality and groundwater contamination. With this foundation, a state may feel that its rationales for uniform regulations, greater expertise, and economic performance are sufficient to support the preemption of local ordinances on the same water issues. Health risks including those related to odors have not been captured by state governments but rather are mainly regulated by local governments. In the absence of comprehensive state regulations, these issues have not been preempted by a state legislature, so local governments are free to adopt odor and health ordinances regulating livestock facilities.

For local issues, implied preemption by a state regulatory system should not be found absent a strong public policy reason (Sarasota Alliance for Fair Elections, Inc. v. Browning, 2010). If a comprehensive regulatory system allows local action, it may not preempt the field (Big Creek Lumber Co. v. Santa Cruz, 2006). Both a state statute and local ordinances can remain effective as long as they do not contain express or implied conditions that irreconcilably conflicted with each other.

State CAFO and livestock facility siting regulations do not regulate all surface water pollution. By not regulating pollutants from small livestock facilities and nonpoint-source pollution from all facilities, a state does not have a comprehensive system. If the state legislature does not explicitly preclude local governments from regulating these sources of water pollution, local governments should be able to proceed with ordinances addressing problems associated with these sources. If a local government feels there are unacceptable pollutants harming its citizens and these are not addressed by a state law, it may act under its police powers. Any local ordinance that regulates unregulated pollutants would be addressing concerns that were not the focus of state law (Smith v. City of Santa Fe, 2006). Thus, there is no overlap so the state law cannot be found to have preempted local ordinances.

\section{Concluding Comments}

Many believe that the replacement of small family farms with large operations threatens the social, economic, and environmental fabric of rural communities (Thorne, 2007). Citizens are concerned about health risks and diminished property values related to pollutant discharges from CAFOs and other livestock producers. By denigrating water and air resources, producers adversely affect human health and the environment. This has led state and local governments to enact laws, ordinances, and regulations to reduce risks and prevent damages. In Wisconsin, the state's livestock facility siting law was found to preempt local regulations on water pollution (Adams v. Wisconsin Livestock Facilities Siting Review Board, 2012). The state's supreme court felt the law's purpose to provide uniform regulations resulted in the withdrawal of a town's power to act on the same subject.

Given the powers granted to local governments and localized needs for controlling pollutants, a state's livestock facilities siting law should be examined closely to determine whether it embodies implied field preemption. Four factors may be scrutinized to determine whether a state law meets the legal prerequisites of implied field preemption. For most situations, a state siting law may regulate numerous aspects of the location of livestock facilities, but not all of them. Local governments should be allowed to regulate those aspects not covered by state law. They can structure local ordinances so that they address different subject matter than delineated in a state's regulatory system.

By investigating the negative externalities that may accompany the production of animals at CAFOs, this study shows states having an interest in fostering the state's economy through uniform state regulations. To achieve its objectives, a state legislature may enact a comprehensive system to regulate water pollution that precludes local regulations. However, local governments have a function in responding to citizen petitions concerning localized water pollution. An evaluation of the problems associated with livestock production shows marked risks and damages at the local level. States have difficulties in enacting regulations that can deal with the multiplicity of localized issues affecting persons residing near livestock facilities. Local governments are intended to provide for their citizens' well-being and have the flexibility to enact local ordinances to control harm. The preemption of local ordinances is contrary to local control and should be used sparingly. 
The different interests of state and local governments suggest that both sets of governments might benefit from greater collaboration facilitating local participation. States could engage in joint state-local cooperation under which the state grants authority to local governments. Under state-local cooperation, a local government could interject regulatory features it feels are needed to control localized pollution from livestock facilities. Minnesota's feedlot regulations incorporate a cooperative approach (Minnesota Statutes, 2013). This example provides an alternative from the more drastic preemption of local ordinances found in Wisconsin.

Local governments deserve to be able to respond to citizen concerns about local water quality. State legislatures advancing comprehensive regulatory systems over water pollution need to proceed cautiously to avoid trammeling options that are needed to control negative externalities at the local level.

\section{Acknowledgments}

The authors gratefully acknowledge funding from the Cooperative State Research Education and Extension Service (CSREES), US Department of Agriculture Project No. GEO00684.

\section{References}

Adams v. Wisconsin Livestock Facilities Siting Review Board. (2012). 820 N.W.2d at 404 (Wisconsin Supreme Court).

Banker, M. I. (2010). I saw the sign: the new federal menu-labeling law and lessons from local experience. Food and Drug Law Journal, 65, 901-928.

Big Creek Lumber Co. v. Santa Cruz. (2006). 136 P.3d at 821 (California Supreme Court).

Burkholder v. Zoning Hearing Board of Richmond Township. (2006). 902 A.2d at 1006. (Commonwealth Court of Pennsylvania).

Burt, C., Bachoon, D. S., Manoylov, K., \& Smith, M. (2013). The impact of cattle farming best management practices on surface water nutrient concentrations, faecal bacteria and algal dominance in the Lake Oconee watershed. Water and Environment Journal, 27, 207-215. http://dx.doi.org/10.1111/j.1747-6593.2012.00343.x

Canadian Connection v. New Prairie Township. (1998). 581 N.W.2d at 391 (Minnesota Court of Appeals).

Carter, N. E. (2007). Agriculture, communities and rural environment initiative: can small family farms and large agribusiness live peacefully in Pennsylvania. Widener Law Journal, 16(4), 1023-1051.

Centner, T. J. (2006). Governmental and unconstitutional takings: when do right-to-farm laws go too far? Boston College Environmental Affairs Law Review, 33(1), 87-148.

Centner, T. J. (2012). Regulating the land application of manure from animal production facilities in the USA. Water Policy, 14(2), 319-335. http://dx.doi.org/10.2166/wp.2011.086

Centner, T. J., \& Newton, G. L. (2008). Meeting environmental requirements for the land application of manure. Journal of Animal Science, 86(11), 3228-3234. http://dx.doi.org/10.2527/jas.2008-1161

Collins, S. R. (2012). Striking the proper balance between the carrot and the stick approaches to animal feeding operation regulation. University of Illinois Law Review, 923-968.

Commonwealth v. Richmond Township. (2010). 2 A.3d at 678 (Commonwealth Court of Pennsylvania).

Copeland, C. (2010). Animal waste and water quality: EPA regulation of concentrated animal feeding operations (CAFOs). Washington, DC: Congressional Research Service.

Craig v. County of Chatham. (2002). 565 S.E.2d at 172 (Supreme Court of North Carolina).

Cronauer, C. N. (2011). Flushing out the Illinois Livestock Management Facilities Act. Valparaiso University Law Review, 45, 637-687.

Dalton, P., Caraway, E. A., Gibb, H., \& Fulcher, K. (2011). A multi-year field olfactometry study near a concentrated animal feeding operation. Journal Air and Waste Management Association, 61(12), 1398-1408. http://dx.doi.org/10.1080/10473289.2011.624256

Dowd, B. M., Press, D., \& Los Huertos, M. (2008). Agricultural nonpoint source water pollution policy: the case of California's central coast. Agriculture, Ecosystems and Environment, 128(3), 151-161. http://dx.doi.org/10.1016/j.agee.2008.05.014

Endres, B. (2008). Coexistence strategies, the common law of biotechnology and economic liability risks. Drake Journal of Agricultural Law, 13(1), 115-148. 
Endres, J. M., \& Grossman, M. R. (2004). Air emissions from animal feeding operations: can state rules help? Penn State Environmental Law Review, 13, 1-51.

Franklin County v. Fieldale Farms Corp. (1998). 507 S.E.2d at 460 (Supreme Court of Georgia).

Glicksman, R. L. (2006). From cooperative to inoperative federalism: the perverse mutation of environmental law and policy. Wake Forest Law Review, 41, 719-803.

Gostin, L. O. (2008). Public health law: power, duty, restraint. Berkeley and Los Angeles: University of California Press.

Government Accountability Office. (2008). Concentrated animal feeding operations: EPA needs more information and a clearly defined strategy to protect air and water quality from pollutants of concern. GAO-08-944, Washington, DC. Retrieved from http://www.gao.gov/new.items/d08944.pdf

Griffith, R. B. (2004). Tales of townships and sewage sludge: do Pennsylvania Statutes preempt local regulation of use of biosolids. Pennsylvania Bar Association Quarterly, 75(1), 87-92.

Groves, C. (2012). To promote compliance with the Clean Water Act, the EPA should pursue a national enforcement initiative to regulate concentrated animal feeding operations. Ecology Law Quarterly, 39(2), 321-343.

Hackney, R. (2010). Don't mess with Houston, Texas: the Clean Air Act and state/local preemption. Texas Law Review, 88(Feb.), 639-668.

Hansen, L. N. (1999). Canadian connection v. New Prairie Township: sniffing out an opening in the doctrines of preemption and conflicts of law, and allowing local governments the authority to regulate odor concerns. Great Plains Natural Resources Journal, 3, 177-195.

Hassinger, W. J. II, Monahan, K. A., Scanlon, T. L., \& Parsons, T. D. (2000). Nutrient management practices among swine operations of various sizes. Journal of the American Veterinary Medicine Association, 217, 1526-1530. http://dx.doi.org/10.2460/javma.2000.217.1526

Helland, E. (1998). Environmental protection in the federalist system: the political economy of NPDES inspections. Economic Inquiry, 36(2), 305-319. http://dx.doi.org/10.1111/j.1465-7295.1998.tb01716.x

Herriges, J. A., Secchi, S., \& Babcock, B. A. (2005). Living with hogs in Iowa: the impact of livestock facilities on rural residential property values. Land Economics, 81(4), 530-546.

Illinois Compiled Statutes Annotated. (2013). Chapter 510, title 77, sections 1-999.

Iowa Code. (2013). Section 331.304A.

Isakson, H. R., \& Ecker, M. D. (2008). An analysis of the impact of swine CAFOs on the value of nearby houses. Agricultural Economics, 39, 365-372. http://dx.doi.org/10.1111/j.1574-0862.2008.00339.x

Jerger, S. (2004). EPA's new CAFO land application requirements: an exercise in unsupervised self-monitoring. Stanford Environmental Law Review, 23, 91-128.

Johnson, K. R. (2012). Immigration and civil rights: state and local efforts to regulate immigration. Georgia Law Review, 46, 609-638.

Kansas Annotated Statutes. (2013). Section 2-1450.

Mallin, M. A., \& Cahoon, L. B. (2003). Industrialized animal production-a major source of nutrient and microbial pollution to aquatic ecosystems. Population and Environment, 24(5), 369-385. http://dx.doi.org/10.1023/A:1023690824045

Minnesota Statutes. (2013). Section 116.07.

Missouri Code of State Regulations. (2013). Title 10, section 20-6-300.

Murphy, L. B. (2008). CAFO grief: using tax grieving procedures to protest industrial animal factories. Journal of Environmental Law and Litigation, 23, 357-400.

Noel, C. (2002). Preemption hogwash: North Carolina's judicial repeal of local authority to regulate hog farms in Craig v. County of Chatham. North Carolina Law Review, 80(6), 2121-2130.

Novak, C. A. (2000). Agriculture's new environmental battleground: the preemption of county livestock regulations. Drake Journal of Agricultural Law, 5(2), 429-470.

Official Code of Georgia. (2013). Sections 2-1-6, 12-5-30.3. 
Oklahoma Statutes. (2014). Title 2, section 8-26.1.

Oregon Revised Statutes. (2014). Section 527.722.

Ostrow, A. P. (2011). Process preemption in federal siting regimes. Harvard Journal of Legislation, 48, 289-341.

Palmquist, R., Roka, F., \& Vukina, T. (1997). Hog operations, environmental effects, and residential property values. Land Economics, 73(1), 114-124. http://dx.doi.org/10.2307/3147081

Pan, L., Yang, S. X., \& DeBruyn, J. (2007). Factor analysis of downwind odours from livestock farms. Biosystems Engineering, 96(3), 387-397. http://dx.doi.org/10.1016/j.biosystemseng.2006.10.017

Parlow, M. J. (2008). Progressive policy-making on the local level: rethinking traditional notions of federalism. Temple Politocal and Civil Rights Law Review, 17, 371-385.

Paudel, K. P., \& McIntosh, C. S. (2005). Country report: broiler industry and broiler litter-related problems in the Southeastern United States. Waste Management, 25(10), 1083-1088. http://dx.doi.org/10.1016/j.wasman.2005.01.023

Paudel, K. P., Bhattarai, K., Gauthier, W. M., \& Hall, L. M. (2009). Geographic information systems (GIS) based model of dairy manure transportation and application with environmental quality consideration. Waste Management, 29(5), 1634-1643. http://dx.doi.org/10.1016/j.wasman.2008.11.028

Pennsylvania Consolidated Statutes. (2013). Title 3, sections 313, 519; title 58, section 3304.

Perkins, N. D. (2009). Principled preemption in an age of interest convergence: preserving the distinction between Pennsylvania's environmental regulation and local land use regulation. Duquesne Law Review, 47, 27-87.

Ramsey County Farm Bureau v. Ramsey County. (2008). 755 N.W.2d at 920 (North Dakota Supreme Court).

Rosenbloom, J. (2012). New day at the pool: state preemption, common pool resources, and non-place based municipal collaborations. Harvard Environmental Law Review, 36, 445-485.

Rumsey, I. C., \& Aneja, V. P. (2014). Measurement and modeling of hydrogen sulfide lagoon emissions from a swine concentrated animal feeding operation. Environmental Science \& Technology, 48, 1609-1617. http://dx.doi.org/10.1021/es403716w

Sarasota Alliance for Fair Elections, Inc. v. Browning. (2010). 28 So.3d at 880 (Florida Supreme Court).

Simpson, R., Marzin, J. S., \& Warrick, J. (2008). Important trends in Pennsylvania land use. Pennsylvania Bar Association Quarterly, 79(1), 47-64.

Smith v. City of Santa Fe. (2006). 133 P.3d at 866 (New Mexico Court of Appeals).

South Carolina Code Annotated. (2013). Section 47-4-160.

Spence, D. B. (2013). Federalism, regulatory lags, and the political economy of energy production. University of Pennsylvania Law Review, 61, 431-508.

Springsteen, E. R. (2009). A proposal to regulated farm animal confinement in the United States and an overeview of current and proposed laws on the subject. Drake Journal of Agricultural Law, 14(3), 437-467.

Sullivan, E. J., \& Solomou, A. (2011). Preserving forest lands for forest uses - land use policies for Oregon forest lands. Journal of Environmental Law and Litigation, 26(1), 179-258.

Thorne, P. S. (2007). Environmental health impacts of concentrated animal feeding operations: anticipating hazards-searching for solutions. Environmental Health Perspectives, 115(2), 296-297. http://dx.doi.org/10.1289/ehp.8831

Town of Pelham v. Browning Ferris Industries of New Hampshire, Inc. (1996). 683 A.2d at 536 (New Hampshire Supreme Court).

Township of Franklin v. den Hollander. (2002). 796 A.2d at 874 (New Jersey Supreme Court).

US Code of Federal Regulations. (2014). Title 40, parts 122 and 412.

US Code. (2012). Title 33, sections 1311, 1342, 1362, 1370.

US Department of Agriculture. (2003). Costs associated with development and implementation of comprehensive nutrient management plans. Washington, DC: Natural Resources Conservation Service.

US EPA. (2008). Revised national pollutant discharge elimination system permit regulation and effluent limitations guidelines for concentrated animal feeding operations in response to the Waterkeeper decision; 
final rule. Federal Register 73 (Nov. 20), 70418-70486.

US EPA. (2009). National water quality inventory: report to Congress-2004 reporting cycle. EPA 841-R-08-001. Washington, DC: Office of Water.

US EPA. (2011). Proposed national pollutant discharge elimination system concentrated animal feeding operations reporting rule. Washington, DC: Office of Water, Office of Wastewater Management, October 2011. Retrieved from http://www.epa.gov/npdes/pubs/2011_npdes_cafo_qa.pdf

US EPA. (2013). NPDES CAFO rule implementation status -- national summary, endyear 2013. Retrieved from http://www.epa.gov/npdes/pubs/tracksum\%20endyear2013.pdf

Wisconsin Statutes. (2012). Chapter 93, section 90.

Worth County Friends of Agriculture v. Worth County. (2004). 688 N.W.2d at 257 (Iowa Supreme Court).

\section{Copyrights}

Copyright for this article is retained by the author(s), with first publication rights granted to the journal.

This is an open-access article distributed under the terms and conditions of the Creative Commons Attribution license (http://creativecommons.org/licenses/by/3.0/). 